\title{
The resizing of the most powerful Italian instrumental earthquake (September 8, 1905, Calabria region, southern Italy)
}

\author{
Luigi Cucci
}

Istituto Nazionale di Geofisica e Vulcanologia, Italy

Article history: received April 8, 2021; accepted September 21, 2021

\begin{abstract}
The 8 September 1905 Calabria earthquake is the seismic event for which the Italian Seismic Catalogue shows the highest instrumental magnitude of the whole dataset. However, the reported $\mathrm{M}_{\mathrm{S}}=7.47$ was calculated over only two stations, and leaves room for a revision. In this work I provide a new estimate of the surface-wave magnitude of the earthquake calculated over sixteen individual values of magnitude from seven different stations. The new estimate is $M_{S}=7.10 \pm 0.21$, a value that is consistently lined up with other estimates provided by means of macroseismic or geological evidence. The novel estimate is stable despite alternative epicentral locations and different depths proposed for this event by several investigators. The net variation of almost half a unit magnitude implies a resizing of the seismogenic source of the event in the frame of the seismotectonics of the region, and highlights the strong need for a systematic revision of the instrumental magnitude estimates for several 'historical' earthquakes that occurred at the dawning of the instrumental seismology.
\end{abstract}

Keywords: Instrumental Seismology; Resizing seismogenic source; Powerful earthquake; September 8, 1905; Calabria region.

\section{Introduction}

The 8 September 1905 Calabria earthquake ranks among the ten most powerful events of the whole Italian seismic history [CPTI 15 Catalogue, Rovida et al., 2021] in terms of default magnitude $\left(\mathrm{M}_{\mathrm{w}}=6.95\right.$, which for this earthquake is calculated from the average of the macroseismic and instrumental magnitudes). In particular, among the earthquakes for which an instrumental magnitude has been estimated, a $\mathrm{M}_{\mathrm{S}}=7.47$ [Margottini et al., 1993] is associated with this event in the CPTI 15 Catalogue. Such a value makes by far the 1905 earthquake the strongest event to have occurred during the instrumental era in Italy, even more than other seismic events that deeply affected the social, economic and environmental background of the Peninsula such as the 1908 Messina $\mathrm{M}=7.10$ [Pino et al., 2000], 1915 Avezzano $M=7.04$ [Margottini et al., 1993], and 1980 Irpinia $M=6.81$ [Rovida et al., 2021] earthquakes. Such a high value probably derives from the shortage of seismological data associated with this earthquake and available to Margottini et al. [1993] to build their dataset. This evidence, along with the awareness that the official magnitude estimate of the event contributed to the assessment of the seismic hazard of this part 


\section{Luigi Cucci}

of the Calabria region, prompted the author that there was room to attempt a revision of the seismological data available for the earthquake and provide an updated value of its surface-wave magnitude because 1) the rapid increase of organized catalogs and bulletins on the Internet has made it easier to access a greater number of seismological data than thirty years ago, 2) this instrumental data in particular is an important input for the evaluation of the magnitude of the 1905 event in the seismic Catalogue, and eventually for the assessment of the seismic hazard of the area.

\section{Overview of the 1905 Calabria earthquake}

The 1905 seismic event belongs to a peculiar group of highly destructive earthquakes, occurred at the dawning of the instrumental seismology, for which the location, geometry and size of the causative source are lively debated and not fully constrained. During the century elapsed since the earthquake, previous Authors identified three different epicentral areas that are more than $50 \mathrm{~km}$ apart and proposed magnitudes ranging from $\mathrm{M}=6.2$ to $\mathrm{M}=7.9$ (Figure 1 and Table 1; for a comprehensive review about this issue see Tertulliani and Cucci, [2009]). The earthquake struck in the early hours of 8 September a vast area of the Tyrrhenian side of the Calabria peninsula (Figure 1), causing the death of 557 people and the heaviest damage ( $\mathrm{I}_{0}=\mathrm{X}-\mathrm{XI}$ in CPTI 15) between the towns of Lamezia and Nicotera (Figure 1). Extensive damage was also reported in the Aeolian Islands and in north-eastern Sicily.

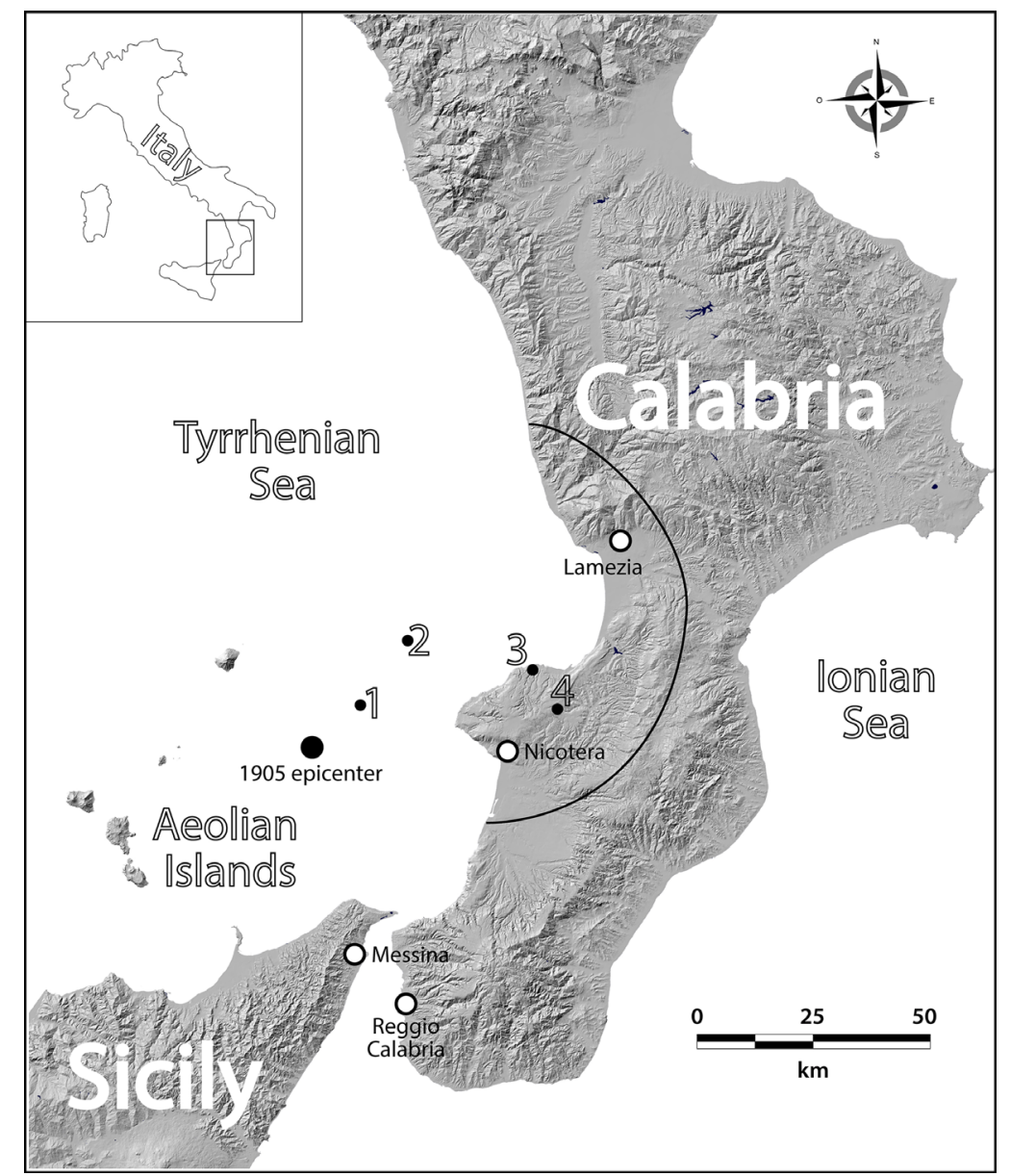

Figure 1. Map of the study area. A black circle indicates the location of the 1905 earthquake by Michelini et al. [2006] currently reported in the CPTI Catalogue. A solid line shows the boundary of the most damaged area. Small black circles numbered 1 to 4 indicate alternative locations proposed by the investigators and quoted in the text. 1: Presti et al. [2017]; 2: Galli and Molin [2009]; 3: Camassi and Stucchi [1997]; 4: Guidoboni et al. [2019]. 
The mainshock originated several ground failures and widespread hydrological changes [Tertulliani and Cucci, $2008 ; 2009$ ] and was followed by a long-lasting seismic sequence composed of hundreds of aftershocks [Guidoboni et al., 2019]. It also generated a moderate tsunami that was observed along a wide stretch of coast in the Southern Tyrrhenian Sea [Maramai et al., 2014].

Focusing on the magnitude estimates associated with this event, several diverging estimates are reported by various authors. For simplicity I have summarized in Table 1 all the estimates of magnitude discussed below. Besides the default magnitude $\mathrm{M}_{\mathrm{w}}=6.95$ reported in the CPTI 15 Catalogue, results from inversions of macroseismic data provided estimates ranging from $\mathrm{M}=6.2$ [Westaway, 1992], to $\mathrm{M}=6.7$ [Guidoboni et al., 2007], $\mathrm{M}=6.8$ [Postpischl, 1985] and $M=7.0$ [Gruppo di lavoro CPTI, 2004]. $M=6.9$ is the macroseismic magnitude presently reported in the CPTI 15 Catalogue. Other values of magnitude were derived from geological and geophysical data $[\mathrm{M} \geq 6.7$, Tertulliani and Cucci 2009; $\mathrm{M}=6$ 6.9, Loreto et al., 2017; $\mathrm{M}=6.8$, DISS Working Group, 2018 and Trippetta et al., 2019]. As regards the calculation of instrumental magnitudes, Duda [1965] provides $\mathrm{M}_{\mathrm{L}}=7.9$ that is the highest estimate in the literature for this earthquake, Kárník [1969] calculates $\mathrm{M}_{\mathrm{L}}=7.3$, and Riuscetti and Schick [1975] and Carrozzo et al. [1975] estimate $M=7.0$. Finally, as already mentioned above, Margottini et al. [1993] calculate a $M_{S}=7.47$ on the basis of the recordings from two stations.

\begin{tabular}{|c|c|c|c|}
\hline SOURCE & M & ORIGIN & NOTES \\
\hline Westaway [1992] & $\mathrm{M}_{\mathrm{R}}=6.2$ & Macros & from isoseismal maps \\
\hline Guidoboni et al. [2019] & $\mathrm{M}_{\mathrm{E}}=6.7$ & Macros & $\begin{array}{l}\text { CFTIMed Catalogue. Equivalent } \\
\text { magnitude based on macroseismic } \\
\text { observations }\end{array}$ \\
\hline Tertulliani and Cucci [2009] & $M \geq 6.7$ & Geol/Geophys & $\begin{array}{l}\text { empirical relationships with } \\
\text { environmental effects }\end{array}$ \\
\hline Postpischl [1985] & $\mathrm{M}_{\mathrm{k}}=6.8$ & Macros & $\begin{array}{l}\text { empirical relationships following } \\
\text { Karnik [1969] }\end{array}$ \\
\hline DISS Working Group [2018] & $\mathrm{M}_{\mathrm{w}}=6.8$ & Geol/Geophys & $\begin{array}{l}\text { derived from data by } \\
\text { Loreto et al. [2017] }\end{array}$ \\
\hline Trippetta et al. [2019] & $\mathrm{FLEM}=6.8$ & Geol/Geophys & fault-length earthquake magnitude \\
\hline Loreto et al. [2017] & $\mathrm{M}_{\mathrm{w}}=6.9$ & Geol/Geophys & $\begin{array}{l}\text { geological/geophysical data using } \\
\text { empirical relationships }\end{array}$ \\
\hline Rovida et al. [2021] & $\mathrm{M}_{\mathrm{W}}=6.9 \pm 0.10$ & Macros & $\begin{array}{l}\text { CPTI15 Catalogue. Calculated using } \\
\text { the code "Boxer" [Gasperini et al. 2010] }\end{array}$ \\
\hline Rovida et al. [2021] & $\mathrm{M}_{\mathrm{WDEF}}=6.95 \pm 0.09$ & Macros/Instr & "default magnitude" \\
\hline Carrozzo et al. [1975] & $\mathrm{M}_{\mathrm{L}}=7.0$ & Instr & $\begin{array}{l}\text { reported also in } \\
\text { Postpischl [1985] }\end{array}$ \\
\hline Riuscetti and Schick [1975] & $\mathrm{M}=7.0$ & Instr & unspecified \\
\hline Gruppo di lavoro CPTI [2004] & $\mathrm{M}_{\mathrm{A}}=7.06 \pm 0.09$ & Macros & $\begin{array}{l}\text { CPTI04 Catalogue. } \\
\text { Mean magnitude }\end{array}$ \\
\hline This work & $\mathrm{M}_{\mathrm{S}}=7.10 \pm 0.21$ & Instr & $\begin{array}{l}\text { calculated over sixteen individual } \\
\text { values of magnitude from seven } \\
\text { different stations }\end{array}$ \\
\hline Karnik [1969] & $\mathrm{M}_{\mathrm{L}}=7.3$ & Instr & based on two registrations \\
\hline Rovida et al. [2021] & $\mathrm{M}_{\text {Wins }}=7.41 \pm 0.29$ & Instr & $\begin{array}{l}\text { CPTI15 Catalogue. Converted from } \\
\text { Margottini et al. [1993] using } \\
\text { Lolli et al. [2014] }\end{array}$ \\
\hline Margottini et al. [1993] & $\mathrm{M}_{\mathrm{S}}=7.47 \pm 0.04$ & Instr & based on two stations \\
\hline Duda [1965] & $\mathrm{M}_{\mathrm{L}}=7.9$ & Instr & Richter magnitude \\
\hline
\end{tabular}

Table 1. Summary of the estimates of magnitude of the 1905 Calabria earthquake. Abbreviations: Macros (Macroseismic); Geol/Geophys (Geological/Geophysical); Instr (Instrumental). 


\section{Luigi Cucci}

\section{Estimate of the surface wave magnitude}

Amplitude and period readings were extracted from the station bulletins available to me from the library of the headquarter of the Istituto Nazionale di Geofisica e Vulcanologia in Rome and on the Internet (see Data and Sharing Resources), and supplemented by readings reported in ISC. Figure 2 shows a map of the seismological observatories recording the data that were investigated in the present work. Surface-wave magnitude $\mathrm{M}_{\mathrm{S}}$ was computed using the Prague formula firstly suggested by Kárník et al. [1962] and officially adopted by IASPEI:

$$
\mathrm{M}_{\mathrm{S}}=\log (\mathrm{A} / \mathrm{T})+1.66 \log \Delta+3.3
$$

where $\mathrm{A} / \mathrm{T}$ is the maximum value of all ratios of the surface-wave groups on a record, $\mathrm{A}$ is the horizontal ground motion (in micrometers) associated with a period $\mathrm{T}$ (in seconds), and $\Delta$ is the epicentral distance (in degrees).

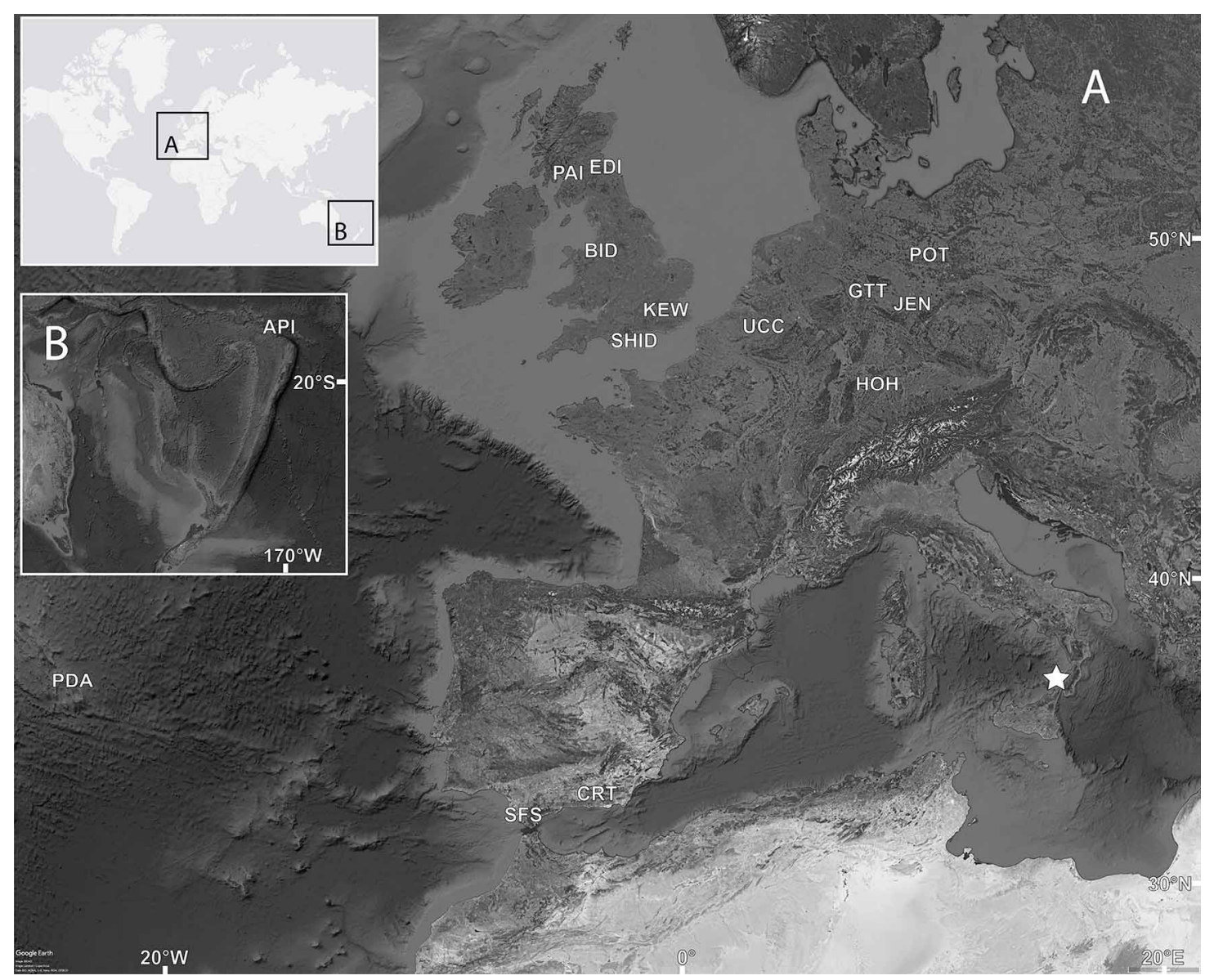

Figure 2. Location of the seismological observatories that provided data. A) European observatories. A white star indicates the location of the 1905 earthquake. B) Extra-European observatories.

In general, the equation (1) is employed over any epicentral distance range; however, in this study all the stations involved in the estimate of the $\mathrm{M}_{\mathrm{S}}$ are located between $12^{\circ}$ and $154^{\circ}$ epicentral distance, thus falling in the interval $\left(2^{\circ}-160^{\circ}\right)$ that is more suitable for such a calculation [Kárník et al., 1962]. Also, the $\mathrm{M}_{\mathrm{S}}$ estimates were calculated without station corrections (except for the not negligible $C_{i}=-0.37$ available for the Potsdam station by Margottini et al. [1993]), as this factor is found to have an overall relatively small effect that does not affect the distance dependence in equation (1) [Ambraseys, 1985; Margottini et al., 1993; Ambraseys and Douglas, 2000]. Single-instrument magnitudes were computed from horizontal components following the procedure employed by Kárník et al. [1962]. Uncertainties in the data extracted from the station bulletins mainly regard the definition of 
the amplitude, i.e., peak-to-peak or zero-to-peak, which sometimes is not specified. For the bulletins from Granada (CRT) and Hohenheim (HOH) I assumed that the reported maximum amplitude corresponds to peak-to-peak readings. In all the cases in which ambiguities could not be resolved the data were discarded. Also, I did not use readings of maximum amplitude if no corresponding period $\mathrm{T}$ was given. For the calculation of station magnitudes, when both the horizontal components were available, the amplitude A was taken as the vector sum of the two components; otherwise, each component was used separately and the calculated $M$ value was increased by 0.1 [Margottini et al., 1993; Ambraseys and Douglas, 2000]. I provide the average of the magnitude estimates for each station; finally, the $\mathrm{M}_{\mathrm{S}}$ magnitude of the 1905 event is calculated from the arithmetic mean of the available station magnitudes. Table 2 shows a summary of all the seismic stations examined. The final estimate of the surface-wave magnitude of the 1905 earthquake is $\mathrm{M}_{\mathrm{S}}=7.10$; this estimate was calculated over sixteen individual values of magnitude from seven different stations, whilst data from other seven stations were discarded. The standard deviation of the estimate is $s d=0.21$. This new result makes the 1905 earthquake about one fourth of the Margottini et al. [1993] estimate in terms of energy released.

\begin{tabular}{|c|c|c|c|c|c|c|c|c|}
\hline $\begin{array}{l}\text { OBSERVATORY } \\
\text { (STATION) }\end{array}$ & $\begin{array}{l}\text { LAT. } \\
\text { LON. }\end{array}$ & DIST. $\left({ }^{\circ}\right)$ & $\begin{array}{c}\text { E-W AMP. } \\
(\mu)\end{array}$ & $\begin{array}{l}\text { PERIOD } \\
\text { (sec) }\end{array}$ & $\begin{array}{c}\text { N-S AMP. } \\
(\mu)\end{array}$ & $\begin{array}{l}\text { PERIOD } \\
\text { (sec) }\end{array}$ & $\begin{array}{l}\text { ESTIMATED } \\
\text { MAGNITUDE }\end{array}$ & $\begin{array}{c}\text { MEAN } \\
\text { STATION } \\
\text { MAGNITUDE }\end{array}$ \\
\hline \multirow{4}{*}{$\begin{array}{l}\text { JENA } \\
\text { (JEN) }\end{array}$} & \multirow{4}{*}{$\begin{array}{l}50.9519 \mathrm{~N} \\
11.5833 \mathrm{E}\end{array}$} & \multirow{4}{*}{12.62} & 335 & 13.5 & 430 & 13.5 & 6.73 & \multirow{4}{*}{6.88} \\
\hline & & & 340 & 9.5 & 500 & 9.5 & 6.93 & \\
\hline & & & 340 & 9.5 & 500 & 9.5 & 6.93 & \\
\hline & & & 340 & 9.5 & 500 & 9.5 & 6.93 & \\
\hline $\begin{array}{l}\text { GRANADA } \\
\text { (CRT) }\end{array}$ & $\begin{array}{c}37.19 \mathrm{~N} \\
3.59806 \mathrm{~W}\end{array}$ & 15.04 & 290 & 5.2 & 66 & 5.2 & 7.01 & 7.01 \\
\hline $\begin{array}{l}\text { SHIDE } \\
\text { (SHID) }\end{array}$ & $\begin{array}{c}50.588 \mathrm{~N} \\
1.286 \mathrm{~W}\end{array}$ & 16.80 & 320 & 10 & 502 & 10 & 7.11 & 7.11 \\
\hline $\begin{array}{l}\text { HOHENHEIM } \\
(\mathrm{HOH})\end{array}$ & $\begin{array}{l}48.7167 \mathrm{~N} \\
9.21667 \mathrm{E}\end{array}$ & 11.00 & 2978 & 10 & 2637 & 8 & 7.52 & 7.52 \\
\hline \multirow{3}{*}{$\begin{array}{l}\text { GOTTINGEN } \\
(\text { GTT })\end{array}$} & \multirow{3}{*}{$\begin{array}{l}51.5464 \mathrm{~N} \\
9.96417 \mathrm{E}\end{array}$} & \multirow{3}{*}{13.45} & 500 & 10 & & & 6.97 & \multirow{3}{*}{6.94} \\
\hline & & & 500 & 15 & & & 6.8 & \\
\hline & & & 550 & 9 & & & 7.06 & \\
\hline $\begin{array}{l}\text { POTSDAM } \\
\text { (POT) }\end{array}$ & $\begin{array}{l}52.3803 \mathrm{~N} \\
13.0678 \mathrm{E}\end{array}$ & 13.85 & 2220 & 16 & & & 7.07 & 7.07 \\
\hline \multirow{5}{*}{$\begin{array}{l}\text { APIA } \\
\text { (API) }\end{array}$} & \multirow{5}{*}{$\begin{array}{l}13.8072 \mathrm{~S} \\
171.775 \mathrm{~W}\end{array}$} & \multirow{5}{*}{154.2} & 42.5 & 21 & & & 7.34 & \multirow{5}{*}{7.19} \\
\hline & & & 17.5 & 19 & & & 7 & \\
\hline & & & 40 & 19 & & & 7.36 & \\
\hline & & & 14 & 18 & & & 6.92 & \\
\hline & & & 37.5 & 18 & & & 7.35 & \\
\hline $\begin{array}{l}\text { OBSERVATORY } \\
\text { (STATION) }\end{array}$ & $\begin{array}{l}\text { LAT. } \\
\text { LON. }\end{array}$ & DIST $\left({ }^{\circ}\right)$ & $\begin{array}{l}\text { AMP. } \\
(\mathrm{mm})\end{array}$ & $\begin{array}{l}\text { PERIOD } \\
\text { (sec) }\end{array}$ & & & & \\
\hline $\begin{array}{l}\text { LIVERPOOL } \\
\text { (BID) }\end{array}$ & $\begin{array}{l}53.401 \mathrm{~N} \\
3.072 \mathrm{~W}\end{array}$ & 19.48 & 8.3 & - & & & & \\
\hline $\begin{array}{l}\text { EDINBURGH } \\
\text { (EDI) }\end{array}$ & $\begin{array}{l}55.925 \mathrm{~N} \\
3.184 \mathrm{~W}\end{array}$ & 21.29 & 7.5 & - & & & & \\
\hline $\begin{array}{l}\text { PAISLEY } \\
\text { (PAI) }\end{array}$ & $\begin{array}{l}55.846 \mathrm{~N} \\
4.431 \mathrm{~W}\end{array}$ & 21.73 & 8.0 & - & & & & \\
\hline $\begin{array}{l}\text { S. FERNANDO } \\
\text { (SFS) }\end{array}$ & $\begin{array}{c}36.46561 \mathrm{~N} \\
6.20553 \mathrm{~W}\end{array}$ & 17.25 & 3.0 & - & & & & \\
\hline $\begin{array}{l}\text { UCCLE } \\
\text { (UCC) }\end{array}$ & $\begin{array}{l}50.7983 \mathrm{~N} \\
4.35944 \mathrm{~W}\end{array}$ & 14.47 & $>19$ & - & & & & \\
\hline $\begin{array}{l}\text { PONTA DELGADA } \\
\text { (PDA) }\end{array}$ & $\begin{array}{c}37.7467 \mathrm{~N} \\
25.6633 \mathrm{~W}\end{array}$ & 32.04 & 2.55 & - & & & & \\
\hline $\begin{array}{l}\text { KEW } \\
(\text { KEW) }\end{array}$ & $\begin{array}{l}51.468 \mathrm{~N} \\
0.313 \mathrm{~W}\end{array}$ & 16.93 & - & - & & & & \\
\hline
\end{tabular}

Table 2. Summary of the seismological data retrieved from the Observatories. The upper part of the Table reports the seven seismic stations for which it was possible to estimate the surface-wave magnitude. The lower part of the Table reports other seven stations that provided only partial data which did not allow an estimate of magnitude. No information is specified regarding the component available for the station API. Records for CRT station were obtained with Stiattesi pendula which have no damping. The period for station SHID is assumed to be similar to that of the earlier phases of registration. 


\section{Luigi Cucci}

\section{Discussion and conclusions}

As it was calculated over a considerably larger number of stations, I suggest that the estimate of the surface-wave magnitude $\left(\mathrm{M}_{\mathrm{S}}=7.10\right)$ proposed in the present work is more robust than $\mathrm{M}_{\mathrm{S}}=7.47$ obtained by Margottini et al. [1993], that was calculated over only two stations and is presently reported in the CPTI 15 Catalogue. Unfortunately, the original documents employed by Margottini et al. [1993] are no longer available (A. Screpanti, personal communication) to carry out a crosscheck between the different datasets. I now consider in the following the other magnitude estimates put forward in the literature by means of different approaches (macroseismic, geologic, geophysical). The 1905 earthquake is quoted in the CPTI Catalogue with $\mathrm{M}=6.9$ calculated from the inversion of macroseismic intensity data by using the code Boxer [Gasperini et al., 2010]. Tertulliani and Cucci [2009] indicate a minimum magnitude $\mathrm{M}=6.7$ on the basis of empirical relations that regulate the distribution of seismically induced environmental effects. Loreto et al. [2017] estimate $\mathrm{M}=6.9$ by combining onshore structural and morphological data with offshore geophysical data. Such estimates are rather homogeneous, and the $\mathrm{M}_{\mathrm{s}}=7.10$ proposed in this paper is lined up with them. On the contrary, the instrumental estimates of the magnitude of the 1905 event span over almost one unit ( $\mathrm{M}=7.0$ - $\mathrm{M}=7.9$ ); a comparison with the magnitude proposed in this paper is not straightforward as I suggest that most of those estimates are affected by severe uncertainties (Kárník [1969] and Margottini et al. [1993] were based on only two stations, and Duda [1965] is considerably overestimated [Abe and Noguchi, 1983]).

Some uncertainties in the source parameters of the 1905 earthquake can potentially affect the robustness of the surface-wave magnitude proposed in this paper. The first issue concerns the depth of the event. Galli and Molin [2009] and Presti et al. [2017], by means of different techniques propose an offshore location at about 30-40 km depth, deeper than most of the earthquakes occurring in this region. Although the Prague formula only applies to shallow-focus earthquakes (the computed Ms may underrepresent the energy of intermediate- and deep-focus earthquakes), a $40 \mathrm{~km}$-deep focus is still within its range of application [Ambraseys and Douglas, 2000; see also Data and Sharing Resources], therefore no adjustment is required in the magnitude estimate for such a depth.

The second issue concerns the epicentral location of the event. For my calculations I used the offshore location reported in the CPTI Catalogue [Michelini et al., 2006]; on the contrary, some investigators [Rizzo, 1906; Camassi and Stucchi, 1997; Guidoboni et al., 2019] propose an inland epicenter some $\sim 50 \mathrm{~km}$ further East that can generate different values of the correction term for the epicentral distance in equation (1). However, a novel estimate based on the latter location would provide a negligible adjustment of \pm 0.01 units of magnitude.

Though the individuation of the most probable seismogenic source responsible for the 1905 earthquake is clearly beyond the scope of the present work, a comparison between my result and the published magnitude estimates allows to put forward some pieces of evidence that can be framed in the seismotectonics of this region. Using the empirical relationships by Wells and Coppersmith [1994] a $\mathrm{M}=7.10$ earthquake could be generated by a 40-50 kmlong source, whilst a $\mathrm{M}=7.47$ event would require a source about twofold in length and almost three times as rupture area. A $\sim 100 \mathrm{~km}$-long and $30 \mathrm{~km}$-wide seismogenic source seems unrealistic in the complex geological structure of the Calabria region, where the crust is densely fractured, and the faults' orientation and kinematics are highly variable. Indeed, such a very large source has never been previously envisioned by the investigators, neither inland [Peruzza et al., 1997; Monaco and Tortorici, 2000; Piatanesi and Tinti, 2002; Cucci and Tertulliani, 2010], nor offshore [Galli and Molin, 2009; Loreto et al., 2013, 2017; DISS Working Group, 2018; Presti et al., 2019; Rovida et al., 2021]. Given the substantial equivalence between $M_{S}$ and $M_{W}$ for 1905-type earthquakes [Wells and Coppersmith 1994; Das et al., 2011] this evidence is equally valid when using $\mathrm{M}_{\mathrm{S}}$ or $\mathrm{M}_{\mathrm{W}}$.

Finally, following the same criteria of compilation and of definition of a single magnitude for an earthquake record of the Catalogue CPTI15 (“default magnitude” in Rovida et al. [2021]), it is possible to derive an updated default magnitude $M=6.90$ (previously $M=6.95$ ) for this earthquake. Both the new $M_{S}=7.10$ and the updated default magnitude $M=6.90$ scale back the prominence of the 1905 event in the seismic landscape of the region. This result (with a net variation of $\mathrm{M}_{\mathrm{S}}$ of almost half a degree) highlights the strong need for a systematic revision of the instrumental magnitude estimates for historical earthquakes, based on all the data available today. The recovery of the seismological data still existing and their preservation from dispersion or final destruction is a critical issue, considering the importance that the instrumental estimates of magnitude have in the evaluation of the expected maximum magnitude and eventually in the determination of the seismic hazard of a region. 


\section{Data and sharing sources}

Seismological and geological data were downloaded from the following seismic Catalogues, Databases and Bulletins: CPTI15, the Parametric Catalogue of Italian Earthquakes (available at https://emidius.mi.ingv.it/CPTI15DBMI15/index_en.htm); CPTI04, Catalogo Parametrico dei Terremoti Italiani (available at https://emidius.mi.ingv.it/CPTI04/); CFTI5Med, Catalogo dei Forti Terremoti in Italia (461 a.C.-1997) e nell'area Mediterranea (760 a.C.-1500) (available at http://storing.ingv.it/cfti/cfti5/); DISS, Database of Individual Seismogenic Sources (available at http://diss.rm.ingv.it/diss/); NT4.1, un catalogo parametrico di terremoti di area italiana al di sopra della soglia del danno (available at https://emidius.mi.ingv.it/NT/CONSNT.html). Data from seismological observatories are available through the website of EuroSeismos at http://storing.ingv.it/es_web/Data/Collection.htm\#Bull. The on-line Bulletin of the International Seismological Centre is available at https://doi.org/10.31905/D808B830. Some informations on the range of applicability of the Prague formula were retrieved by iaspei.org/pub/commissions/CSOI/Summary_WG_recommendations_20130327.pdf

Acknowledgements. Thanks to the Associate Editor of the journal I. Molinari. The revisions carried out by A. Michelini and by an anonymous reviewer provided important comments and suggestions that strongly improved the quality of the paper. Also, I am indebted to N.A. Pino, who read corrected and provided important comments and suggestions to a previous draft of the manuscript.

\section{REFERENCES}

Abe, K. and S. Noguchi (1983). Revision of magnitudes of large shallow earthquakes, 1897-1912, Phys. Earth Planet. Int., 33, 1-11.

Ambraseys, N.N. (1985). Magnitude assessment of Northwestern European earthquakes, Earth. Eng. Struct. Dyn., 13, 307-320.

Ambraseys, N.N. and J. Douglas (2000). Reappraisal of surface wave magnitudes in the Eastern Mediterranean region and the Middle East, Geophys. J. Int., 141, 357-373.

Camassi, R. and Stucchi M. (eds) (1997). NT4.1: un catalogo parametrico di terremoti di area italiana al di sopra della soglia di danno (versione 4.1.1). Milano, 93.

Carrozzo, M.T., M. Cosentino, A. Ferlito, F. Giorgetti, G. Patanè and M. Riuscetti (1975). Earthquakes Catalogue of Calabria and Sicily (1783-1973), Quaderni de “La Ricerca Scientifica”, 93, CNR, Roma, 194.

Cucci, L. and A. Tertulliani (2010). The Capo Vaticano (Calabria) coastal terraces and the 1905 M7 earthquake: the geomorphological signature of the regional uplift and coseismic slip in southern Italy, Terra Nova, 22, 5, 378389, http://dx.doi.org/10.1111/j.1365-3121.2010.00961.x.

Das, R., H.R. Wason and M.L. Sharma (2011). Global regression relations for conversion of surface wave and body wave magnitudes to moment magnitude, Nat. Hazards 59, 801-810, doi: 10.1007/s11069-011-9796-6.

DISS Working Group (2018). Database of Individual Seismogenic Sources (DISS), Version 3.2.1: A compilation of potential sources for earthquakes larger than M 5.5 in Italy and surrounding areas. http://diss.rm.ingv.it/diss/, Istituto Nazionale di Geofisica e Vulcanologia, doi:10.6092/INGV.IT-DISS3.2.1.

Duda, S.J. (1965). Secular seismic energy release in the Circum-Pacific belt, Tectonophysics, 2, 5, 409-452.

Galli, P. and D. Molin (2009). Il terremoto del 1905 in Calabria: revisione della distribuzione degli effetti e delle ipotesi sismogenetiche, Il Quaternario - Italian Journal of Quaternary Sciences, 22, 2, 207-234.

Gasperini, P., G. Vannucci, D. Tripone and E. Boschi E. (2010). The Location and Sizing of Historical Earthquakes Using the Attenuation of Macroseismic Intensity with Distance, Bull. Seismol. Soc. Am., 100, 20352066, https://doi.org/10.1785/0120090330

Gruppo di lavoro CPTI (2004). Catalogo Parametrico dei Terremoti Italiani (CPTI04). Istituto Nazionale di Geofisica e Vulcanologia (INGV), Bologna, https://doi.org/10.6092/INGV.IT-CPTI04

Guidoboni, E., G. Ferrari, D. Mariotti, A. Comastri, G. Tarabusi and G. Valensise (2007). CFTI4Med, Catalogue of Strong Earthquakes in Italy (461 B.C.-1997) and Mediterranean Area (760 B.C.-1500), INGV-SGA. http://storing.ingv.it/cfti4med/ 


\section{Luigi Cucci}

Guidoboni, E., G. Ferrari, G. Tarabusi, G. Sgattoni, A. Comastri, D. Mariotti, C. Ciuccarelli, M.G. Bianchi and G. Valensise (2019), CFTI5Med, the new release of the catalogue of strong earthquakes in Italy and in the Mediterranean area, Scientific Data 6, Article number: 80 (2019), doi:_https://doi.org/10.1038/s41597-019-0091-9

Karnik, V., N. Kondorskaya, J. Riznichenko, E. Savarenski, S. Solovyov, N. Shebalin, J. Vanek and A. Zatopel (1962). Standardisation of the earthquake magnitude scale, Studia Geophys. Geodet., 6, 41-47.

Karnik, V. (1969). Seismicity of the European Area, Part. 1, 364. Reidel, Dordrecht.

Loreto, M.F., U. Fracassi, A. Franzo, P. Del Negro, F. Zgur and L. Facchin (2013). Approaching the seismogenic source of the Calabria 8 September 1905 earthquake: new geophysical, geological and biochemical data from the S. Eufemia Gulf (S Italy), Mar. Geol., 343, 62-75, http://dx.doi.org/10.1016/j.margeo.2013.06.016.

Loreto, M.F., G. Pagnoni, F. Pettenati, A. Armigliato, S. Tinti, D. Sandron, F. Brutto, F. Muto, L. Facchin and F. Zgur (2017). Reconstructed seismic and tsunami scenarios of the 1905 Calabria earthquake (SE Tyrrhenian sea) as a tool for geohazard assessment, Eng. Geol., 224, 1-14, doi: dx.doi.org/10.1016/j.enggeo.2017.04.018.

Maramai, A., B. Brizuela and L. Graziani (2014). The Euro-Mediterranean Tsunami Catalogue. Ann. Geophys., 57, 4, doi:10.4401/ag-6437.

Margottini, C., N.N. Ambraseys and A. Screpanti (1993). La magnitudo dei terremoti italiani del XX secolo. ENEA, rapporto interno, Roma, 57.

Michelini, A., A. Lomax, A. Nardi and A. Rossi (2006). La localizzazione del terremoto della Calabria dell' 8 settembre 1905 da dati strumentali. In: 8 Settembre 1905, Terremoto in Calabria (I. Guerra and A. Savaglio, eds), pp. 225240. Universita` della Calabria, Calabria.

Monaco, C. and L. Tortorici (2000). Active faulting in the Calabrian arc and eastern Sicily, J. Geodyn., 29, 407-424.

Peruzza, L., D. Pantosti, D. Slejko and G. Valensise (1997). Testing a new hybrid approach to seismic hazard assessment: an application to the Calabrian Arc (Southern Italy), Nat. Hazards, 14, 113-126.

Piatanesi, A. and S. Tinti (2002). Numerical modelling of the September 8, 1905 Calabrian (southern Italy) tsunami, Geophys. J. Int., 150, 271-284, http://dx.doi.org/10.1046/j.1365-246X.2002.01700.x.

Pino, N.A., D. Giardini and E. Boschi (2000). The December 28, 1908, Messina Straits, Southern Italy, earthquake: waveform modelling of regional seismograms, J. Geoph. Res., 105, B11, 2547325492, https://doi.org/10.1029/2000JB900259.

Postpischl, D. (ed.) (1985). Atlas of isoseismal Maps of Italian Earthquakes, Quaderni de “La Ricerca Scientifica”, 114, 2A, 164.

Presti, D., G. Neri, B. Orecchio, S. Scolaro and C. Totaro (2017). The 1905 Calabria, southern Italy, earthquake: Hypocenter location, causative process, and stress changes induced in the area of the 1908 Messina Straits earthquake, Bull. Seismol. Soc. Am., 107, 6, 2613-2623.

Presti, D., C. Totaro, G. Neri and B. Orecchio (2019). New Earthquake Data in the Calabrian Subduction Zone, Italy, Suggest Revision of the Presumed Dynamics in the Upper Part of the Subducting Slab, Seism. Res. Lett., 90, 5, doi: $10.1785 / 0220190024$

Riuscetti, M. and R. Shick (1975). Earthquakes and tectonics in Southern Italy, Boll. Geof. Teor. Appl.,17, 59-78.

Rizzo, G.B. (1906). Sopra il calcolo della profondità degli ipocentri nei movimenti sismici, Atti Regia Accademia delle Scienze di Torino, 6, 1061-1066.

Rovida, A., M. Locati, R. Camassi, B. Lolli, P. Gasperini and A. Antonucci (2021). Catalogo Parametrico dei Terremoti Italiani (CPTI15), versione 3.0. Istituto Nazionale di Geofisica e Vulcanologia (INGV), https://doi.org/10.13127/CPTI/CPTI15.3

Tertulliani, A. and L. Cucci (2008). Fenomeni associati al terremoto della Calabria del 1905, Quaderni di Geosifica, 60, 4-17.

Tertulliani, A. and L. Cucci (2009). Clues to the identification of a seismogenic source from environmental effects: the case of the 1905 Calabria (Southern Italy) earthquake, Nat. Hazards Earth Syst. Sci., 9, 1787-1803.

Trippetta, F., P. Petricca, A. Billi, C. Collettini, M. Cuffaro, A.M. Lombardi, D. Scrocca, G. Ventura, A. Morgante and C. Doglioni (2019). From mapped faults to fault-length earthquake magnitude (FLEM): a test on Italy with methodological implications, Solid Earth, 10, 1555-1579, https://doi.org/10.5194/se-10-1555-2019.

Wells, D. and K. Coppersmith (1994). New empirical relationship among magnitude, rupture length, rupture width, rupture area and surface displacement, Bull. Seismol. Soc. Am. 84, 974-1002.

Westaway, R. (1992). Seismic moment summation for historical earthquakes in Italy: tectonic implications, J. Geophys. Res., 97, 15.437-15.464. 
The resizing of the 1905 Calabria earthquake

CORRESPONDING AUTHOR: Luigi CUCCI, Istituto Nazionale di Geofisica e Vulcanologia, Rome, Italy e-mail: luigi.cucci@ingv.it (c) 2021 the Author(s). All rights reserved. Open Access. This article is licensed under a Creative Commons Attribution 3.0 International 